\title{
New member of editorial board: PD Dr. Petra Stute
}

\section{Petra Stute}

Published online: 1 November 2013

(c) Springer-Verlag Berlin Heidelberg 2013

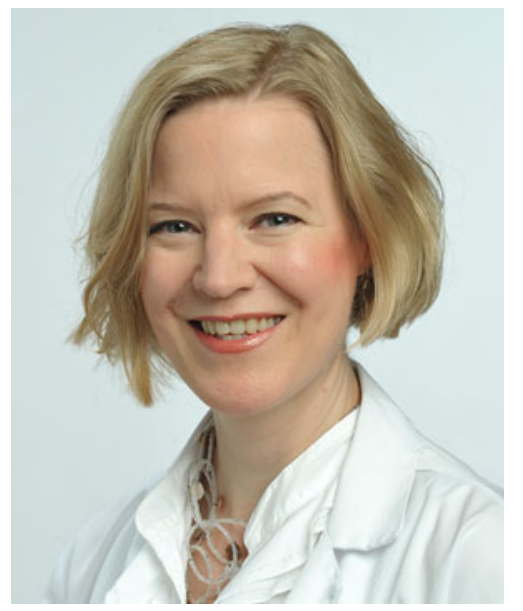

Petra Stute was resident at the Department of Obstetrics and Gynecology, University Clinic Cologne (1998-2001) and the Department of Obstetrics and Gynecology, University Clinic of Münster (2002-2009). In 2005, she received the board certification for Gynecology and Obstetrics, and in 2008 the board certified sub-specialization in Gynecological Endocrinology and Reproductive Medicine. Since 2009, she is the deputy director of the section Gynecological Endocrinology and Reproductive Medicine at the Women's Hospital, University Clinic Bern,
Switzerland. During her scientific career, she spent 1.5 years as a post-doctoral researcher at Wake Forest University (WFU) School of Medicine, Comparative Medicine in Winston-Salem, NC, US, which led to a lasting scientific cooperation. Here, her scientific focus on normal mammary gland endocrine regulation was set. In 2008, Petra Stute received her "Habilitation" at the University of Muenster. Her work has earned several awards and scholarships such as Cologne Fortune Scholarship (2001, 2002), Scholarship from the German Society of Gynecology and Obstetrics (2006), ISGE Young Investigator Award (2006), Christian-Lauritzen Award, German Menopause Society (2006), New Investigator Award, North American Menopause Society (2006), scholarship from the German Menopause Society (2009), Award "Herzstiftung Olten" (2012) and Burgergemeinde Bern (2013). Petra Stute is a board member in several scientific societies such as German Menopause Society, Swiss Menopause Society, and Swiss Society Against Osteoporosis. She is the editor of the bimonthly "First to know" newsletter of the German Menopause Society, the editor of the journal "Gynäkologische Endokrinologie" Krause \&Pachernegg GmbH, and co-editor of "Frauengesundheit und Menopause" in the journal "Gynäkologische Endokrinologie" Springer Medizin Verlag. 